\section{Kidney \\ Blood Pressure \\ Research}

Kidney Blood Press Res 2013;38:1-10

DOI: 10.1159/000355748

Published onlıne: Januar 28, 2014

Accepted: December 13, 2013

(C) 2014 S. Karger AG, Base

www.karger.com/kbr

1423-0143/14/0381-0001\$39.50/0

This is an Open Access article licensed under the terms of the Creative Commons AttributionNonCommercial 3.0 Unported license (CC BY-NC) (www.karger.com/OA-license), applicable to

the online version of the article only. Distribution permitted for non-commercial purposes only.

\title{
Renal Tubular Dysfunction in Sickle Cell Disease
}

\author{
Geraldo B. Silva Junior ana Patrícia F. Vieira ${ }^{a}$ Amanda X. Couto Bem ${ }^{a}$ \\ Marília P. Alves $^{a}$ Gdayllon C. Meneses ${ }^{c}$ Alice M.C. Martins ${ }^{c} \quad$ Talita R. Sanches ${ }^{d}$ \\ Lúcia C. Andrade $^{d}$ Antonio C. Seguro ${ }^{d} \quad$ Alexandre B. Libório ${ }^{b}$ Elizabeth F. Daher $^{\mathrm{a}}$ \\ aPost-Graduation Program in Medical Sciences, Department of Internal Medicine, School of Medicine, \\ Federal University of Ceará; 'bSchool of Medicine, Health Sciences Center, University of Fortaleza; \\ 'Department of Clinical and Toxicological Analysis, School of Pharmacy, Federal University of Ceará, \\ Fortaleza, Ceará; 'Division of Nephrology, School of Medicine, University of São Paulo, São Paulo, Brazil
}

\section{Key Words}

Sickle cell disease - Kidney disease • Tubular dysfunction • Renal function tests • Renal tubular acidosis

\begin{abstract}
Background/Aims: Kidney abnormalities are one of the main chronic complications of sickle cell disease (SCD). The aim of this study is to investigate the occurrence of renal tubular abnormalities among patients with SCD. Methods: This is a prospective study with 26 SCD adult patients in Brazil. Urinary acidification and concentration tests were performed using calcium chloride $\left(\mathrm{CaCl}_{2}\right)$, after a $12 \mathrm{~h}$ period of water and food deprivation. Fractional excretion of sodium ( $\mathrm{FE}_{\mathrm{Na}}$ ), transtubular potassium gradient (TTKG) and solute free water reabsorption $\left(\mathrm{TcH}_{2} \mathrm{O}\right)$ were calculated. The SCD group was compared to a group of 15 healthy volunteers (control group). Results: Patient's average age and gender were similar to controls. Urinary acidification deficit was found in 10 SCD patients (38.4\%), who presented urinary $\mathrm{pH}>5.3$ after $\mathrm{CaCl}_{2}$ test. Urinary osmolality was significantly lower in SCD patients (355 \pm 60 vs. $818 \pm 202 \mathrm{mOsm} / \mathrm{kg}, \mathrm{p}=0.0001$, after $12 \mathrm{~h}$ period water deprivation). Urinary concentration deficit was found in all SCD patients $(100 \%)$. $\mathrm{FE}_{\mathrm{Na}}$ was higher among SCD patients $(0.75 \pm 0.3 \mathrm{vs}$. $0.55 \pm 0.2 \%, p=0.02)$. The TTKG was higher in SCD patients ( $5.5 \pm 2.5$ vs. $3.0 \pm 1.5, p=0.001$ ), and $\mathrm{TcH}_{2} \mathrm{O}$ was lower $(0.22 \pm 0.3$ vs. $1.1 \pm 0.3 \mathrm{~L} /$ day, $\mathrm{p}=0.0001)$. Conclusions: $\mathrm{SCD}$ is associated with important kidney dysfunction. The main abnormalities found were urinary concentrating and incomplete distal acidification defect. There was also an increase in the potassium transport and decrease in water reabsorption, evidencing the occurrence of distal tubular dysfunction.
\end{abstract}




\section{Kidney \\ Blood Pressure Research}

Silva Jr./Vieira/Couto Bem et al.: Sickle Cell Nephropathy

\section{Introduction}

Sickle cell disease (SCD) is the most frequent hematologic hereditary disorder in the world, and the prevalence of sickle cell trait is around 7\% [1, 2]. The disease is characterized by multisystem involvement, with episodes of acute illness and progressive organ damage [2].

Kidney involvement in SCD includes a variety of glomerular and tubular disorders, which are associated with increased mortality [3-5]. The pathophysiology of sickle cell nephropathy includes the polymerization of erythrocytes into renal medulla, a region which predisposes to this phenomenon due to its low local oxygen pressure, low $\mathrm{pH}$, and high osmolality [4, 6]. These alterations lead to renal tubular function abnormalities, including urinary concentrating and acidification defects, and glomerular hyperfiltration due to an increased prostaglandin production, which can in turn lead to glomerulosclerosis $[4,5]$.

It is estimated that $4-12 \%$ of SCD patients will develop life-threatening end-stage renal disease [5], and this picture can be even worse because the life expectancy of these patients are increasing and so are the complications associated with the chronic course of the disease. The exact incidence and clinical course of sickle cell nephropathy is unknown, as well as all the mechanisms involved in its pathogenesis.

The aim of the present study is to investigate glomerular and tubular dysfunction in adult SCD patients through traditional and new renal tubular function tests, highlighting important possible novel aspects on its pathophysiology.

\section{Patients and Methods}

\section{Patients' selection}

This is a prospective cohort study with 26 consecutive patients with clinical and laboratory diagnosis of SCD (hemoglobin SS) undergoing consultation in a public health service in Brazil from December 2010 to June 2012. The patients were selected in the outpatients`clinics of Hematology Service. Those who agreed to participate in the study and who gave their written informed consent were included, unless they had any exclusion criteria as patients under 18 years or older than 65 years, use of nephrotoxic drugs, hypertension (systolic blood pressure $\geq 140$ or diastolic blood pressure $\geq 90 \mathrm{mmHg}$ ), diabetes mellitus, urinary tract infections, systemic lupus erythematosus, collagen vascular disorder and other conditions which could affect kidney function. The 26 patients were compared with 15 healthy volunteers (randomly selected among blood donors). None of the controls had sickle cell trait.

\section{Ethics}

The protocol of this study was revised and approved by the Ethical Committee of the Walter Cantidio University Hospital, Federal University of Ceará, Fortaleza, Brazil. Patients were included in the study after signing the informed consent form.

SCD Diagnosis

All patients had a definitive diagnosis of SCD with hemoglobin electrophoresis. All of them were homozygous and presented hemoglobin S (HbSS).

Protocol of treatment

All patients were treated with folic acid $5 \mathrm{mg} /$ day and 12 with hydroxyurea $1 \mathrm{~g} /$ day (since 1 to 2 years).

Group Definition

A comparison between the studied parameters was done between the study group and controls.

Clinical and laboratory parameters

At the time of medical consult all symptoms and signs were evaluated and the following data were recorded: race, age, gender, previous chronic diseases (heart failure, arterial hypertension and diabetes 


\section{Kidney \\ Blood Pressure Research}

Kidney Blood Press Res 2013;38:1-10

\begin{tabular}{l|l}
\hline DOI: 10.1159/000355748 & (C) 2014 S. Karger AG, Basel
\end{tabular}

Published online: Januar 28, 2014

www.karger.com/kbr

Silva Jr./Vieira/Couto Bem et al.: Sickle Cell Nephropathy

mellitus), use of drugs, blood pressure and weight. The following laboratory parameters were evaluated: total blood count, plasma urea $\left(\mathrm{P}_{\mathrm{Ur}}\right)$, creatinine $\left(\mathrm{P}_{\mathrm{Cr}}\right)$, sodium $\left(\mathrm{P}_{\mathrm{Na}}\right)$, potassium $\left(\mathrm{P}_{\mathrm{K}}\right)$, fasting glucose, osmolality $\left(\mathrm{P}_{\text {osm }}\right)$, arterial $\mathrm{pH}$ and bicarbonate $\left(\mathrm{HCO}_{3}\right)$ A 24-hour urinary volume (UV) sample was collected for creatinine $\left(\mathrm{U}_{\mathrm{Cr}}\right)$, urea $\left(\mathrm{U}_{\mathrm{Ur}}\right)$, sodium $\left(\mathrm{U}_{\mathrm{Na}}\right)$, potassium $\left(\mathrm{U}_{\mathrm{K}}\right)$ and albuminuria measurements. Urine samples were collected for osmolality $\left(\mathrm{U}_{\mathrm{osm}}\right)$ and $\mathrm{pH}\left(\mathrm{U}_{\mathrm{pH}}\right)$ determination, as described below.

Kidney function evaluation

Glomerular filtration rate (GFR) was calculated by 24-hour urine collection for creatinine measurement. Severe kidney function loss was considered when GFR was $<60 \mathrm{~mL} / \mathrm{min} / 1.73 \mathrm{~m}^{2}$. Glomerular hyperfiltration was considered as GFR $>120 \mathrm{~mL} / \mathrm{min} / 1.73 \mathrm{~m}^{2}$. Albuminuria was determined by 24 -hour urine collection and abnormal values were considered when $>30 \mathrm{mg} /$ day. To assess tubular function, fractional excretion of sodium $\left(\mathrm{FE}_{\mathrm{Na}}\right)$ was calculated through standard formula. Solute free water reabsorption $\left(\mathrm{TcH}_{2} \mathrm{O}\right)$ was calculated by the formula: $\mathrm{Tc}_{\mathrm{H} 2 \mathrm{O}}=\operatorname{Cosm}-\mathrm{V}$ (where $\operatorname{Cosm}=\mathrm{U}_{\mathrm{osm}_{\mathrm{m}}} \mathrm{V} / \mathrm{P}_{\mathrm{osm}} ; \mathrm{V}=$ urinary flow), and the transtubular potassium gradient (TTKG) by the formula: TTKG $=\left(\mathrm{P}_{\text {osm }} \times \mathrm{U}_{\mathrm{K}}\right) /\left(\mathrm{P}_{\mathrm{K}} \times \mathrm{U}_{\text {osm }}\right)$.

All patients underwent food and water deprivation for 12 hours. Urinary concentration ability was evaluated through the ratio between urinary and serum osmolality $\left(\mathrm{U}_{\text {osm }} / \mathrm{P}_{\text {osm }}\right)$ after 12 hours water deprivation. Urinary acidification was evaluated through the measure of urinary $\mathrm{pH}$ before and after administration of oral $\mathrm{CaCl}_{2} 2 \mathrm{mEq} / \mathrm{kg}\left(\mathrm{T}_{0}\right.$ and $\left.\mathrm{T}_{4}\right)$, as it is more tolerable than ammonium chloride [7]. Acidification defect was determined by the inability in decreasing $\mathrm{U}_{\mathrm{pH}}$ for less than 5.3 after the administration of the acid load, as described before [8].

\section{Analytical methods}

Urea was determined by colorimetric uricase method (Labtest $\left.{ }^{\boxplus}\right)$. The results were expressed in $\mathrm{mg} / \mathrm{dL}$. Serum and urinary creatinine were determined by colorimetric method, picric acid, Taussky and Bonsness $\left(\right.$ Labtest $\left.^{\circledR}\right)$. The results were expressed in $\mathrm{mg} / \mathrm{dL}$. Serum and urinary sodium and potassium $\left(\mathrm{P}_{\mathrm{Na}+}\right.$ and $\left.\mathrm{P}_{\mathrm{K}+}\right)$ were determined by photometry technique with spectrophotometry, model B462 MICRONAL (Instrumentation Laboratory, Inc. USA). The results were expressed in $\mathrm{mEq} / \mathrm{L}$. Glucose was determined by colorimetric glucose oxidase method (Labtest $\left.{ }^{\circledast}\right)$. The results were expressed in $\mathrm{mg} / \mathrm{dL}$. Arterial $\mathrm{pH}$ and bicarbonate (HCO3) were determined through "Blood gas analyzer" machine (chiron diagnostic 238 Bayer $\left.{ }^{\circledR}\right)$. The results were expressed in $\mathrm{mEq} / \mathrm{L}$ for bicarbonate. Urinary $\mathrm{pH}\left(\mathrm{U}_{\mathrm{pH}}\right)$ was measured by $\mathrm{pHmetro}$ Digital pG1000, model GEHAKALT. Urinary osmolality was determined by the technique pressure steam in osmometer model 5100C (Wescor Inc., USA). The results were expressed in mOsm $/ \mathrm{Kg}$. $\mathrm{H}_{2} \mathrm{O}$. Albuminuria was measured through immunoturbidimetry methods, using Tina-quant ${ }^{\circledR}$ kit (Roche) and the results were expressed in $\mathrm{mg} /$ day.

\section{Statistical analysis}

The SCD group was analyzed as a general group and was compared with the control group. A comparison between SCD patients according to the use of hydroxyurea and age was also done. Fisher's exact test and $\mathrm{X}^{2}$ test were used to analyze allele frequencies in the patients' group. Differences between two independent variables were evaluated using Student's t test or Mann-Whitney test as appropriate. Data were expressed as means $\pm \mathrm{SD}$, and $\mathrm{p}<0.05$ was considered statistically significant. The SPSS software for Windows, release 10.0 (SPSS Inc., Chicago, Ill., USA) was used in all analyses.

\section{Results}

\section{Subject characteristics}

A total of 26 SCD patients were studied, with a mean age of 32.1 \pm 9.9 years (range 20-53 years), and 16 (61\%) were females. There was no significant difference regarding age, gender, mean arterial blood pressure and body weight between the SCD and control group (Table 1). All patients had sickle cell anemia (HbSS) and a mean fetal hemoglobin of $10.9 \pm 6.9 \%$ at the time of the last medical visit. Patients with SCD had lower levels of hemoglobin $(9.1 \pm 1.4 \mathrm{vs.}$ $13 \pm 1.3 \mathrm{~g} / \mathrm{dl}, \mathrm{p}=0.0001$ ) and hematocrit ( $26 \pm 4.2 \mathrm{vs} .41 \pm 4.2 \%, \mathrm{p}=0.0001)$ than controls, as well as higher leukocytes count $\left(9725 \pm 3065\right.$ vs. $\left.6350 \pm 489 / \mathrm{mm}^{3}, \mathrm{p}=0.0001\right)$. Platelets count had 


\section{Kidney \\ Blood Pressure Research}

a tendency to be higher among SCD patients $(367944 \pm 151808$ vs. $\quad 286333 \pm 49143 / \mathrm{mm}^{3}$, $\mathrm{p}=0.05$ ). The mean value of $\mathrm{HbF}$ in patients taking hydroxyurea was $11 \pm 6 \%$ and in those not taking hydroxyurea was $10 \pm 7 \%$, but this difference was not statistically significant $(p=0.69)$.

\section{Kidney function evaluation Glomerular filtration} rate and proteinuria. GFR was similar in both groups $(114 \pm 53$ vs. $\quad 102 \pm 17 \mathrm{ml} / \mathrm{min} / 1.73 \mathrm{~m}^{2}$, $\mathrm{p}=0.40$ ). Glomerular hyperfiltration was found in 9 SCD patients (34.6\%). GFR $<60 \mathrm{ml} /$ min $/ 1.73 \mathrm{~m}^{2}$ was observed in 3 cases $(11.5 \%)$. The distribution of patients according to GFR and the classification of chronic kidney disease is illustrated in Figure 1. Albuminuria was higher among SCD patients than in controls ( $66 \pm 121$ vs. $6.5 \pm 6 \mathrm{mg} /$ day, $\mathrm{p}=0.0001$ ), as shown in Table 2. Microalbuminuria was found in 7 cases (27\%). Diuresis was higher in SCD patients than in controls $(1819 \pm 704$ vs. $1028 \pm 273, \quad \mathrm{p}=0.0002)$. The distribution of patients according to the occurrence of proteinuria is shown in Figure 2.

Sodium, potassium and water tubular transport. In basal conditions, SCD group had a sinificantly higher $\mathrm{FE}_{\mathrm{a}}$ $(0.75 \pm 0.3$ vs. $0.55 \pm 0.2 \%$, $\mathrm{p}=0.02)$, TTKG $(5.5 \pm 2.5$ vs. $3.0 \pm 1.5, \mathrm{p}=0.001)$ and $\mathrm{TcH}_{2} \mathrm{O}$ $(0.22 \pm 0.3$ vs. $1.1 \pm 0.3 \mathrm{~L} /$ day, $\mathrm{p}=0.0001$ ), when compared to the control group (Table 2).

Urinary concentration ability. When the maximum urinary concentration ability was assessed, patients in the
Table 1. Demographic and clinical characteristics of patients with SCD compared to controls

\begin{tabular}{lccc}
\hline & $\begin{array}{c}\text { SCD group } \\
(\mathrm{n}=26)\end{array}$ & $\begin{array}{c}\text { Control } \\
(\mathrm{n}=15)\end{array}$ & $P$ \\
\hline Age, years & $32.1 \pm 9.9$ & $28.4 \pm 10$ & 0.25 \\
Gender & $10(39 \%)$ & $6(40 \%)$ & 1.0 \\
$\quad$ Male & $16(61 \%)$ & $9(60 \%)$ & \\
$\quad$ Female & $118 \pm 13$ & $112 \pm 12$ & 0.15 \\
SBP, $m m H g$ & $71 \pm 10$ & $69 \pm 13$ & 0.41 \\
DBP, $m m H g$ & $58 \pm 11$ & $61 \pm 9.1$ & 0.46 \\
Weight, Kg & $10.9 \pm 6.9$ & - & - \\
Fetal Hb (\%) & (median 8$)$ & - & - \\
Hydroxyurea & $12(46 \%)$ & - & \\
\hline
\end{tabular}

SBP - Systolic blood pressure; DBP - diastolic blood pressure. Data are shown as means \pm SD or numbers with percentages in parentheses.

$P<0.05$ was considered significant

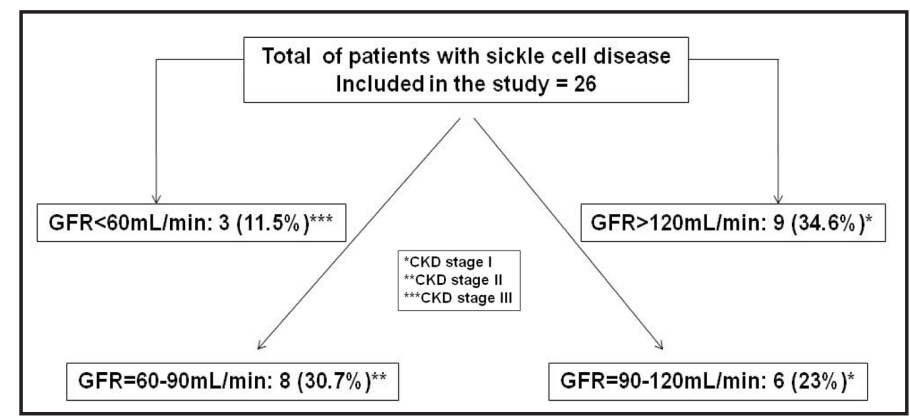

Fig. 1. Distribution of patients according to the glomerular filtration rate and the stages of chronic kidney disease.

Table 2. Comparison of renal function parameters between patients with SCD and controls

\begin{tabular}{|c|c|c|c|}
\hline Parameters & $\begin{array}{c}\text { SCD } \\
(\mathrm{N}=26)\end{array}$ & $\begin{array}{l}\text { Control } \\
(\mathrm{N}=15)\end{array}$ & $P$ \\
\hline $\mathrm{P}_{\mathrm{Ur}}, m g / d L$ & $19 \pm 8.4$ & $24 \pm 6.6$ & 0.09 \\
\hline $\mathrm{P}_{\mathrm{Cr}}, m g / d L$ & $0.7 \pm 0.3$ & $0.8 \pm 0.1$ & 0.22 \\
\hline GFR, $\mathrm{mL} / \mathrm{min} / 1.73 \mathrm{~m}^{2}$ & $114 \pm 53$ & $102 \pm 17$ & 0.40 \\
\hline Microalbuminuria, mg/day & $66 \pm 121$ & $6.5 \pm 6$ & 0.0001 \\
\hline $\mathrm{FE}_{\mathrm{Na}}, \%$ & $0.75 \pm 0.3$ & $0.55 \pm 0.2$ & 0.02 \\
\hline $\mathrm{S}_{\mathrm{Na},} m E q / L$ & $137 \pm 2.3$ & $139 \pm 1.3$ & 0.003 \\
\hline $\mathrm{S}_{\mathrm{K},} m E q / L$ & $4.3 \pm 0.5$ & $4.2 \pm 0.2$ & 0.46 \\
\hline $\mathrm{U}_{\mathrm{Na}}, m E q / L$ & $127 \pm 46$ & $122 \pm 26$ & 0.70 \\
\hline $\mathrm{U}_{\mathrm{K}}, m E q / L$ & $31 \pm 15$ & $31 \pm 9$ & 1.0 \\
\hline $\mathrm{Posm}, \mathrm{mOsm} / \mathrm{KgH}_{2} \mathrm{O}$ & $285 \pm 6.4$ & $284 \pm 5.0$ & 0.60 \\
\hline TTKG & $5.5 \pm 2.5$ & $3.0 \pm 1.5$ & 0.001 \\
\hline $\mathrm{Tc}_{\mathrm{H} 2 \mathrm{O}}, L /$ day & $0.22 \pm 0.3$ & $1.1 \pm 0.3$ & 0.0001 \\
\hline Diuresis (mL/day) & $1819 \pm 704$ & $1028 \pm 273$ & 0.0002 \\
\hline
\end{tabular}

$\mathrm{P}_{\mathrm{Cr}}$ - plasma creatinine, $\mathrm{P}_{\mathrm{Ur}}$ - plasma urea, UProt - $24 \mathrm{~h}$-urinary protein, GFR - glomerular filtration rate, $\mathrm{FE}_{\mathrm{Na}}$ - sodium excretion fraction, $\mathrm{S}_{\mathrm{Na}}-$ serum sodium, $\mathrm{S}_{K}$ - serum potassium, $\mathrm{P}_{\mathrm{osm}}$,- plasma osmolality, TTKGtranstubular potassium gradient, $\mathrm{Tc}_{\mathrm{H}} \mathrm{20}$-solute free water reabsorption. Data are shown as mean \pm SD. Significant $P<0.05$

SCD group had lower $U_{\text {osm }}(355 \pm 60$ vs. $818 \pm 202 \mathrm{mOsm} / \mathrm{Kg}, \mathrm{p}=0.0001)$ after a $12 \mathrm{~h}$ period of water deprivation when compared to controls, as well as lower $U_{\text {osm }} / P_{\text {osm }}(1.1 \pm 0.2$ vs. 2.8 \pm 0.7 , 


\section{Kidney \\ Blood Pressure Research}

$\mathrm{p}=0.0001$ ), as can be seen in Table 3. All SCD patients had the relation $\mathrm{U}_{\text {osm }} / \mathrm{P}_{\text {osm }}$ lower than 2.8, evidencing urinary concentration inability.

\section{Urinary acidification} ability. The $\mathrm{U}_{\mathrm{pH}}$ before $\mathrm{CaCl}_{2}$ load was higher in the SCD group when compared to controls ( $5.9 \pm 0.3$ vs. $5.6 \pm 0.5, \mathrm{p}=0.02$ ). The inability to decrease urinary $\mathrm{pH}$ to less than 5.3 after use of $\mathrm{CaCl}_{2}$ was observed in 10 patients (38.4\%) as shown in Table 3. Patients' response to $\mathrm{CaCl}_{2}$ load, according to urinary $\mathrm{pH}$ values, is illustrated in Figure 3. There were 3 patients with after load $\mathrm{pH}<5.0$. Serum bicarbonate $\left(\mathrm{HCO}_{3}\right)$ was lower in SCD patients before $(24 \pm 1.7$ vs. $\quad 26 \pm 3.3 \mathrm{mEq} / \mathrm{l}, \quad \mathrm{p}=0.01$ ) and after $\mathrm{CaCl}_{2}$ test $(22 \pm 1.8$ vs. $\quad 24 \pm 3.4 \mathrm{mEq} / \mathrm{l}, \quad \mathrm{p}=0.01$ ). Arterial pH was similar in both groups before and after the $\mathrm{CaCl}_{2}$ load, while urine $\mathrm{pH}$ was higher among SCD patients, as a possible consequence of urinary acidification inability (Table 3). There was only one patient with metabolic acidosis, which was associated with renal failure (GRF $=62 \mathrm{ml}$ / min). Urinary $\mathrm{pH}$ for this patient was 6.1 before $\mathrm{CaCl}_{2}$ load and 6.0 after $\mathrm{CaCl}_{2}$ load. The distribution of patients according to the occurrence of urinary concentration and acidification deficits and proteinuria is shown in Figure 4.

\section{Discussion}

The results of the present study clarify important aspects of glomerular and tubular dysfunction in SCD patients. They were all asymptomatic, which calls our attention to the

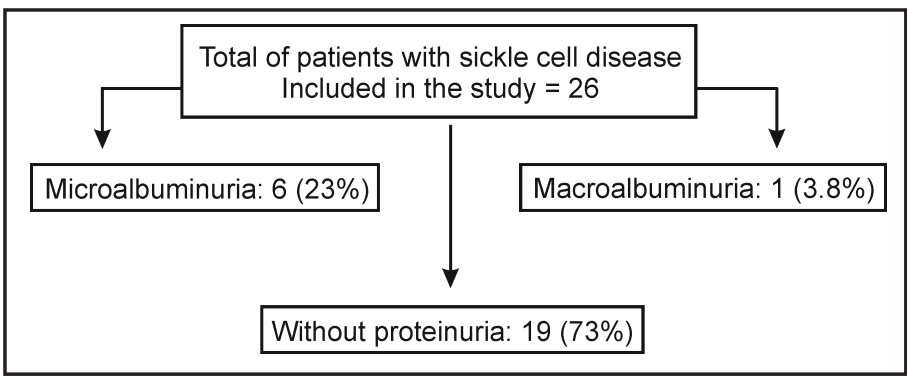

Fig. 2. Distribution of patients according to the occurrence of proteinuria.

Table 3. Comparison of concentration and acidification test results between patients with SCD and controls

\begin{tabular}{lccc}
\hline Parameters & $\begin{array}{c}\text { SCD } \\
(\mathrm{N}=21)\end{array}$ & $\begin{array}{c}\text { Control } \\
(\mathrm{N}=15)\end{array}$ & $P$ \\
\hline $\mathrm{U}_{\text {osm }}, \mathrm{mOsm} / \mathrm{kg}$ & $355 \pm 60$ & $818 \pm 202$ & 0.0001 \\
$\mathrm{U}_{\text {osm }} / \mathrm{P}_{\text {osm }}$ & $1.18 \pm 0.21$ & $2.8 \pm 0.7$ & 0.0001 \\
Arterial pH $\mathrm{T} 0$ & $7.35 \pm 0.03$ & $7.37 \pm 0.04$ & 0.07 \\
Arterial $\mathrm{pH}$ T4 & $7.34 \pm 0.03$ & $7.35 \pm 0.03$ & 0.31 \\
$\mathrm{HCO}_{3} \mathrm{To}, \mathrm{mEq} / \mathrm{L}$ & $24 \pm 1.7$ & $26 \pm 3.3$ & 0.01 \\
$\mathrm{HCO}_{3} \mathrm{~T} 4, \mathrm{mEq} / \mathrm{L}$ & $22 \pm 1.8$ & $24 \pm 3.4$ & 0.01 \\
$\mathrm{U}_{\mathrm{pH}} \mathrm{T0}$ & $5.9 \pm 0.3$ & $5.6 \pm 0.5$ & 0.02 \\
$\mathrm{U}_{\mathrm{pH} 4}$ & $5.3 \pm 0.3$ & $5.1 \pm 0.3$ & 0.04 \\
\hline
\end{tabular}

$\mathrm{U}_{\text {osm }}$ - urinary osmolality, $\mathrm{U} / \mathrm{P}_{\mathrm{osm}}$ - ratio urinary and plasmatic

osmolality, $\mathrm{U}_{\mathrm{pH}} \mathrm{T} 0$ - urinary $\mathrm{pH}$ in $\mathrm{T}_{0}, \mathrm{U}_{\mathrm{pH}} \mathrm{T} 4$ - urinary $\mathrm{pH}$ in $\mathrm{T}_{4}$. Data are shown as mean \pm SD. Significant $P<0.005$

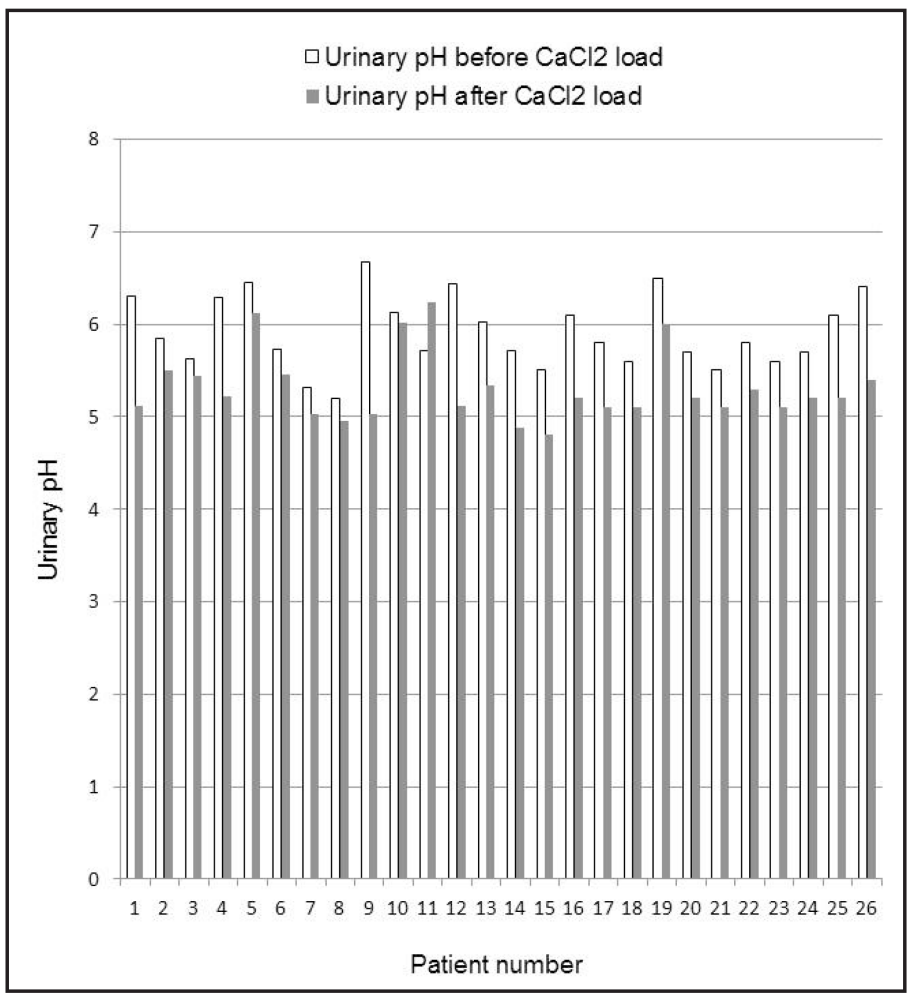

Fig. 3. Urinary $\mathrm{pH}$ values before and after $\mathrm{CaCl}_{2}$ load in patients with sickle cell disease. 


\section{Kidney Blood Pressure Research}

Fig. 4. Distribution of patients according to the occurrence of urinary concentration and acidification deficit.

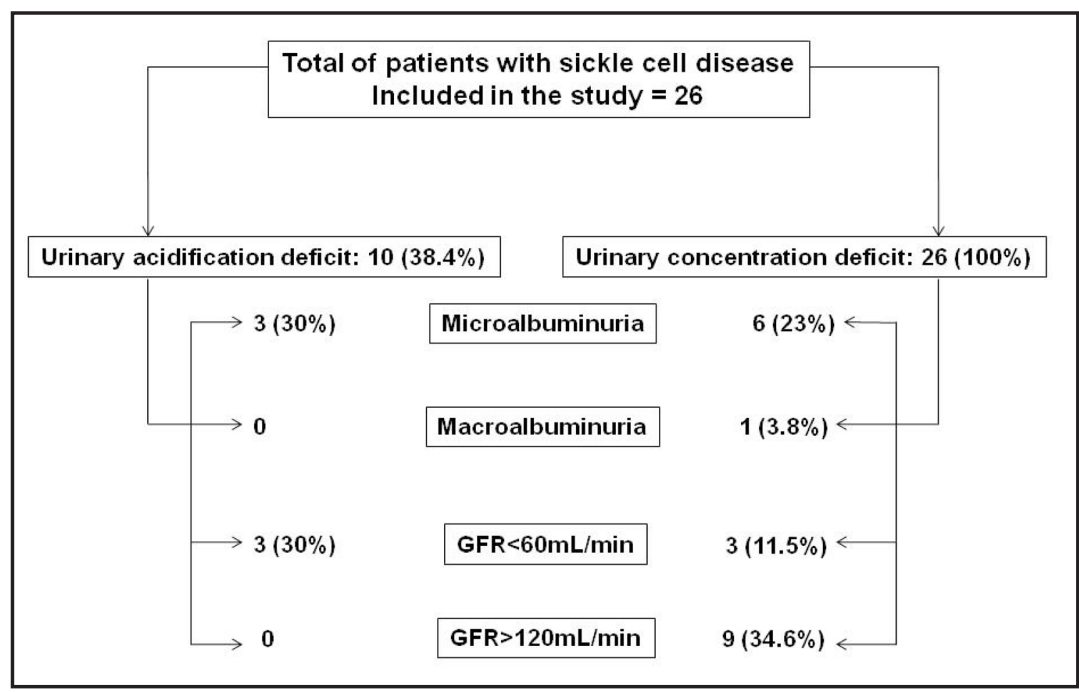

importance of performing regular kidney function assessment in all SCD patients, including more specific tests, such as the urinary concentration and acidification tests.

Kidney involvement in SCD has been observed since the first official case of the disease reported in literature, which described the presence of increased diuresis and urine of low specific gravity [9].

Functional and anatomical renal lesions have been described as a consequence of red blood cell sickling in the vasa recta of the renal medulla [10]. It has been recently demonstrated that renal function loss in SCD is associated with hemolysis. Glomerular filtration rate presented a significant correlation with reticulocyte count and bilirubin [11].

In the present study, there was no difference in the mean glomerular filtration rate (GFR) between patients and controls, however there was a significant number of SCD patients with decreased GFR $\left(<60 \mathrm{~mL} / \mathrm{min} / 1.73 \mathrm{~m}^{2}\right)$, which was found in $11.5 \%$ of cases, which is higher than the previous found in another study in our region, which found a prevalence of GFR $<60 \mathrm{~mL} / \mathrm{min} / 1.73 \mathrm{~m}^{2}$ in $5.1 \%$ of SCD patients [12]. We have identified 3 patients with renal failure, probably corresponding to chronic kidney disease, and all these 3 patients had concentration and acidification deficit. When excluding these patients still $30 \%$ have incomplete tubular acidosis. There were also a significant number of patients with glomerular hyperfiltration (34.6\%). An increase in renal blood flow and glomerular filtration is frequently observed in SCD, becoming apparent around 1 year after birth and tending to decrease with aging $[13,14]$. In a cohort of 85 children with SCD, $76 \%$ had glomerular hyperfiltration [15]. In a recent study performed in our region, hyperfiltration was found in $53 \%$ of SCD patients [12], which was higher than the found in the present study.

In a study investigating renal acidification ability in SCD patients, increased GFR was found as a rule in HbSS patients, mainly in the younger age groups [10]. The incidence of glomerular hyperfiltration in SCD varies from $76 \%$ in children to $14 \%$ in adults $[15$, 16]. The main long-term effect of glomerular hyperfiltration is GFR decrease due to glomerulosclerosis. The most common glomerulopathy observed in SCD patients is focal and segmental glomerulosclerosis, which can be a result of glomerular hyperfiltration $[5,17]$.

In the present study significant microalbuminuria, which is an early predictor of glomerular lesion, was observed in $27 \%$ of cases, which is lower than the described in previous studies [18-24]. This difference could be attributable to differences in genetics, includuing different haplotypes. The levels of albuminuria were higher among the younger patients in our cohort, evidencing that this is one of the first manifestations of sickle cell nephropathy. Alvarez et al. [21] have found similar results but showed a significant association between 


\section{Kidney Blood Pressure Research}

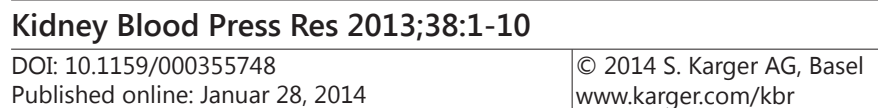

Published onlıne: Januar 28, 2014

Silva Jr./Vieira/Couto Bem et al.: Sickle Cell Nephropathy

proteinuria and serum cystatin C. Cystatin $\mathrm{C}$ also has an inverse correlation with GFR in SCD [15]. Novel biomarkers are under investigation for use in SCD. Urinary kidney injury molecule-1 (KIM-1) and N-acetyl-b-D-glucosaminidase (NAG) presented a strong correlation with albuminuria in a recent cohort of 116 patients with SCD [25]. Urine endothelin-1 was also found to be associated with microalbuminuria in SCD patients, as well as with urinary concentration defect [26]. Albuminuria has been described in 16 to $60 \%$ of adults with SDC $[5,18,20-22,27]$, and has significant correlation with age $[11,19,24]$. No patient in our cohort developed nephrotic range proteinuria, which is really rare in SCD [5]. Proteinuria is an early manifestation of sickle cell glomerulopathy and should be investigated in all patients with SCD $[13,22]$.

Renal sodium handling was evaluated by $\mathrm{FE}_{\mathrm{Na}}$ measurements and it was found to be significantly higher among SCD group. TTKG was also higher in SCD group and $\mathrm{TcH}_{2} \mathrm{O}$ was lower, suggesting an increased transtubular potassium transport and a higher salt and water lost, pointing to a renal salting wasting syndrome in SCD. A renal salt-losing state has been suggested to explain the low incidence of hypertension in patients with SCD [17]. In fact the levels of blood pressure were similar between SCD patients and controls in our study. It is described that the increase in sodium and water loss from the collecting duct leads to a reactive increase in sodium and water reabsorption by the proximal tubule [5], but even with this possible increase in sodium reabsorption the $\mathrm{FE}_{\mathrm{Na}}$ was higher in SCD patients than in controls, which suggests a possible proximal tubular defect. The loss of other substances, such as glucose, amino acids, phosphate and bicarbonate should also be performed in SCD, configuring Fanconi Syndrome, which has been described in SCD patients, but it was attributable to deferoxamine use [28]. It is possible that SCD could cause Fanconi Syndrome. No patient in our cohort was using deferoxamine, so if they had Fanconi Syndrome, it could be attributable to SCD itself. A distal tubule defect could also be responsible for $\mathrm{FE}_{\mathrm{Na}}$ increase in our patients. Since we have no data on glycosuria, hypophosphatemia and hypouricemia we cannot state that these patients have a proximal tubule defect.

Impaired reabsorption of solute free water in the distal convoluted tubules and collecting ducts is also supposed to occur in SCD, as suggested by Crosley Jr. \& Strickland [29] in one of the first reported cases of renal concentration defect associated with SCD. It is believed that the kidney failure to acidify the urine to a normal extent implies a disturbed exchange of $\mathrm{H}^{+}$ions for $\mathrm{Na}^{+}$, so it is expected that abnormal acidification in SCD is accompanied by impairment in the sodium conservation [10]. Further studies are required to better comprehend proximal tubular dysfunction in SCD. The higher TTKG observed in SCD patients evidence an increased potassium transport in distal tubules, despite serum potassium was normal in all cases. A high TTKG is suggestive of inappropriate renal loss of potassium, if serum levels are normal [30]. Distal tubule function is often impaired in SCD, leading to reduced potassium and hydrogen excretion and an incomplete renal tubular acidosis type IV [5]. Higher TTKG is described in the setting of hyperaldosteronism [31], which is another possible explanation to our findings, although it is unlikely. It is known that plasma renin and aldosterone production can be increased in the presence of medullary fibrosis in patients with SCD [3], which could be responsible for some of the abnormalities found in our cohort. Unfortunately it was not possible to dose these hormones levels in our patients, due to technical institutional difficulties. Impaired concentrating defect could explain TTKG difference. Diuresis was also higher among SCD patients, which could be due to concentrating deficit and could also impact on potassium transport.

Abnormal urinary concentrating ability was present in all studied cases, and this is the most common tubular abnormality in SCD [3]. Urinary osmolality was significantly lower in SCD patients than in controls. The inability to concentrate urine under conditions of water deprivation (hyposthenuria) is a very frequent event in $\mathrm{SCD}^{5}$, and this begins in childhood. Enuresis is a common finding in children with SCD, which is described in more than $60 \%$ of patients, reflecting urinary concentration defect [32]. It is described that patients with SCD can concentrate urine only to a maximum of $400-450 \mathrm{mOsm} / \mathrm{kg}$ after $8-10 \mathrm{~h}$ of water 


\section{Kidney Blood Pressure Research}

deprivation, in comparison with normal subjects $[33,34]$, and this inability seem to be associated with age [33].

Our patients had a very low urine osmolality (mean $355 \pm 60 \mathrm{mOsm} / \mathrm{Kg}$ after 12 -hour water deprivation period, which points to a severe urinary concentration inability. All of them had no symptom, but are at high risk of dehydrating when facing long periods of water deprivation and if they were under extreme heat conditions. Patients with higher levels of $\mathrm{HbF}$ have a greater ability to concentrate urine [35]. The mean fetal hemoglobin in our patients was $10.9 \%$, which is similar to previous studies describing renal abnormalities in SCD [22], and this could not be identified as a protective factor, since the majority of patients had low $\mathrm{HbF}$ levels (only 5 patients had $\mathrm{HbF}>10 \%$, median was $8 \%$ ). A possible action to do would be to administrate hydroxyurea to all these patients, in order to increase $\mathrm{HbF}$ levels and maybe improve renal function, but long-term studies would be necessary to assess this possible benefit.

A recent study with 160 children with different renal diseases found a significant association between the inability to concentrate urine and glomerular filtration rate [36], but we did not found this in our cohort, since all patients had urinary concentration defect and the majority of them had normal GFR. The urinary concentration deficit in SCD is associated with red blood cells sickling and sickle cell crisis, with a possible reversion being described with repeated blood transfusions [37]. Urinary concentration process requires an intact collecting duct. The juxtamedullary nephron collecting ducts extend deepest into the medulla and are capable of generating the highest urine concentrations. If reabsorbed sodium is not removed efficiently, as a result of sluggish blood flow due to sickling, sodium reabsorption in the collecting ducts is reduced. The normal medullary concentration gradient necessary for water reabsorption is lost, low-grade sickling persists and medullary congestion develops [3].

We found urinary acidification defect in $38.4 \%$ of the studied patients. This abnormality is less frequent than urinary concentration defect, and is described as a form of incomplete renal tubular acidosis. Ho \& Alleyne [38] investigated the urinary acidification capacity 8 SCD adult patients by administrating ammonium chloride, as the first type of renal acidification capacity test described [39], and they found a mean urine $\mathrm{pH}$ of 5.42, which was lower than in controls (mean 4.85). These authors, however, did not state how many patients presented $\mathrm{pH}<5.5$, which could be considered normal after an acid load. Goossens et al. [10] also found urinary acidification deficit in patients with SCD, and the prevalence of this defect was higher than the observed in the present study (75\% among $\mathrm{HbSC}$ patients and 92\% in $\mathrm{HbSS}$ ).

\section{Study limitations}

Study limitations include the small number of patients (it was not possible to investigate all patients followed in our service). It was not possible to determine GFR through a goldstandard method such as inulin clearance or DTPA and no measurement of ammonium excretion nor titrable acid were performed due to technical limitations of our hospital. We also did not have data regarding $\mathrm{PO}_{2}$ and $\mathrm{PCO}_{2}$ to better characterize the acid-base disorders among the studied patients. The laboratory had only provided the values of $\mathrm{pH}$ and $\mathrm{HCO}_{3}$.

\section{Conclusion}

SCD is associated with important kidney dysfunction. The main abnormality found was urinary concentrating deficit, which was observed in all studied patients. Urinary acidification deficit was also frequent (found in almost $40 \%$ of cases). The higher $\mathrm{FE}_{\mathrm{Na}}$ points to a possible proximal tubular damage, while the increase in the potassium transport and decrease in water reabsorption evidences the occurrence of distal tubular dysfunction. Continued kidney function assessment is important for all SCD patients because the majority of them are symptomatic and there are possible measures that could be done to slow the progression 


\section{Kidney \\ Blood Pressure Research}

Kidney Blood Press Res 2013;38:1-10

\begin{tabular}{l|l}
\hline DOI: 10.1159/000355748 & (C) 2014 S. Karger AG, Basel
\end{tabular}

Published online: Januar 28, 2014

www.karger.com/kbr

Silva Jr./Vieira/Couto Bem et al.: Sickle Cell Nephropathy

of kidney disease, such as the use of angiotensin-converting enzyme inhibitors, angiotensin II receptor blockers and hydroxyurea. Novel techniques are important to elucidate some aspects of the pathophysiology of sickle cell nephropathy.

\section{Conflict of Interests}

There is no conflict of interest. The results presented in this paper have not been published previously in whole or part, except in abstract format.

\section{References}

1 Wang WC: Sickle cell anemia and other sickling syndromes. In: Greer JP, Foerster J, Rodgers GM, Paraskevas F, Glader B, Arber DA, Means RT Jr (eds) Wintrobe's Clinical Hematology, $12^{\text {th }}$ ed. Lippincott Williams \& Wilkins, Philadelphia, 2009, pp. 1038-1082.

-2 Rees DC, Williams TN, Gladwin MT: Sickle-cell disease. Lancet 2010;276:2018-2031.

-3 Scheinman JI: Sickle cell disease and the kidney. Nat Clin Pract Nephrol 2009;5:78-88.

4 Silva Junior GB, Libório AB, Daher EF: New insights on pathophysiology, clinical manifestations, diagnosis, and treatment of sickle cell nephropathy. Ann Hematol 2011;90:1371-1379.

-5 Sharpe CC, Thein SL: Sickle cell nephropathy - a practical approach. Br J Haematol 2011; 155:287-297.

-6 López Revuelta K, Ricard Andrés MP: Kidney abnormalities in sickle cell disease. Nefrología 2011; 31:591601.

7 Oster JR, Hotchkiss JL, Carbon M, Farmer M, Vaamonde CA: A short duration renal acidification test using calcium chloride. Nephron 1975;14:281-292.

8 Walsh SB, Shirley DG, Wrong OM, Unwin RJ: Urinary acidification assessed by simultaneous furosemide and fludrocortisones treatment: an alternative to ammonium chloride. Kidney Int 2007;71:1310-1316.

-9 Herrick J: Peculiar elongated and sickle-shaped red blood corpuscles in a case of severe anemia. Arch Intern Med 1910;6:517-521.

10 Goossens JP, Statius van Eps LW, Schouten H, Giterson AL: Incomplete renal tubular acidosis in sickle cell disease. Clin Chim Acta 1972;41:149-156.

11 Day TG, Drasar ER, Fulford T, Sharpe CC, Thein SL: Association between hemolysis and albuminuria in adults with sickle cell anemia. Haematologica 2012;97:201-205.

-12 Silva Junior GB, Libório AB, Vieira AP, Bem AX, Lopes Filho AS, Figueiredo Filho AC, Guedes AL, Souza JH, Costa CM, Costa R, Daher EF: Evaluation of renal function in sickle cell disease patients in Brazil. Braz J Med Biol Res 2012;45:652-655.

13 Wigfall DR, Ware RE, Burchinal MR, Kinney TR, Foreman JW: Prevalence and clinical correlates of glomerulopathy in children with sickle cell disease. J Pediatr 2000;136:749-753.

14 Ware RE, Rees RC, Sarnaik SA, Iyer RV, Alvarez OA, Casella JF, Shulkin BL, Shalaby-Rana E, Strife CF, Miller JH, Lane PA, Wang WC, Miller ST; BABY HUG Investigators: Renal function in infants with sickle cell anemia: baseline data from the BABY HUG trial. J Pediatr 2010;156:66-70.

15 Aygun B, Mortier NA, Smeltzer MP, Hankins JS, Ware RE: Glomerular hyperfiltration and albuminuria in children with sickle cell anemia. Pediatr Nephrol 2011;26:1285-1290.

-16 Voskaridou E, Terpos E, Michail S, Hantzi E, Anagnostopoulos A, Margeli A, Simirloglou D, Loukopoulos D, Papassotiriou I: Early markers of renal dysfunction in patients with sickle cell/ $\beta$ - thalassemia. Kidney Int 2006;69:2037-2042.

17 Saborio P, Scheinman JI: Sickle cell nephropathy. J Am Soc Nephrol 1999;10:187-192.

-18 Sesso R, Almeida MA, Figueiredo MS, Bordin JO: Renal dysfunction in patients with sickle cell anemia or sickle cell trait. Braz J Med Biol Res 1998;31:1257-1262.

19 Guasch A, Navarrete J, Nass K, Zayas CF: Glomerular involvement in adults with sickle cell hemoglobinopathies: prevalence and clinical correlates of progressive renal failure. J Am Soc Nephrol 2006;17:2228-2235. 


\section{Kidney \\ Blood Pressure Research}

\begin{tabular}{|c|c|}
\hline Kidney Blood Press Res 2 & \\
\hline $\begin{array}{l}\text { DOI: } 10.1159 / 000355748 \\
\text { Published online: Januar 28, } 2014\end{array}$ & $\begin{array}{l}\text { (c) } 2014 \text { S. Karger AG, Basel } \\
\text { www.karger.com/kbr }\end{array}$ \\
\hline
\end{tabular}

Silva Jr./Vieira/Couto Bem et al.: Sickle Cell Nephropathy

20 Aleem A: Renal abnormalities in patients with sickle cell disease: a single center report from Saudi Arabia. Saudi J Kidney Dis Transpl 2008;19:194-199.

-21 Alvarez O, Lopez-Mitnik G, Zilleruelo G: Short-term follow-up of patients with sickle cell disease and albuminuria. Pediatr Blood Cancer 2008;50:1236-1239.

22 Aleem A: Proteinuria in adult Saudi patients with sickle cell disease is not associated with identifiable risk factors. Saudi J Kidney Dis Transpl 2010;21:903-908.

23 Abdu A, Emokpae MA, Uadia PO, Kuliya-Gwarzo A: Proteinuria among adult sickle cell anemia patients in Nigeria. Ann Afr Med 2011;10:34-37.

-24 Arogundade FA, Sanusi AA, Hassan MO, Salawu L, Durosinmi MA, Akinsola A: An appraisal of kidney dysfunction and its risk factors in patients with sickle cell disease. Nephron Clin Pract 2011;118:c225-c231.

-25 Sundaram N, Bennett M, Wilhelm J, Kim MO, Atweh G, Devarajan P, Malik P: Biomarkers for early detection of sickle nephropathy. Am J Hematol 2011;86:559-566.

-26 Tharaux PL, Hagège I, Placier S, Vayssairat M, Kanfer A, Girot R, Dussaule JC: Urinary endothelin-1 as a marker of renal damage in sickle cell disease. Nephrol Dial Transplant 2005;20; 2408-2413.

27 McPherson Yee M, Jabbar SF, Osunkwo I, Clement L, Lane PA, Eckman JR, Guasch A: Chronic kidney disease and albuminuria in children with sickle cell disease. Clin J Am Soc Nephrol 2011;6:2628-2633.

28 Rheault MN, Bechtel H, Neglia JP, Kashtan CE: Reversible Fanconi Syndrome in a pediatric patient on Deferasirox. Pediatr Blood Cancer 2011;56:674-676.

29 Crosley Jr. AP, Strickland WH: Renal function in sickle cell anemia. J Natl Med Assoc 1961;53:39-40.

30 Choi MJ, Ziyadeh FN: The utility of the transtubular potassium gradient in the evaluation of hyperkalemia. J Am Soc Nephrol 2008;19:424-426.

-31 Ethier JH, Kamel KS, Magner PO, Lemman Jr J, Halperin ML: The transtubular potassium concentration in patients with hypokalemia and hyperkalemia. Am J Kidney Dis 1990;15:309-315.

-32 Suster G, Oski FA: Enuresis in sickle cell anemia. Am J Dis Child 1967;113:311.

-33 Statius van Eps LW, Schouten H, Haar Romeny-Wachter CC, La Porte-Wijsman LW: The relation between age and renal concentrating capacity in sickle cell disease and hemoglobin C disease. Clin Chim Acta 1970;27:501-511.

-34 Allon M: Renal abnormalities in sickle cell disease. Arch Intern Med 1990;150:501-504.

35 Becker AM: Sickle cell nephropathy: challenging the conventional wisdom. Pediatr Nephrol 2011;26:20992109.

-36 Garcia Nieto VM, Yanes MIL, Zamorano MM, González MJH, Aros CP, Garin EH: Renal concentrating capacity as a marker for glomerular filtration rate. Acta Paediatr 2008;97:96-99.

37 Keitel HG, Thompson D, Itano HA: Hyposthenuria in sickle cell anemia: a reversible renal defect. J Clin Invest 1956;35:998-1007.

-38 Ho PK, Alleyne GA: Defect in urinary acidification in adults with sickle cell anaemia. Lancet 1968;2:954955.

-39 Wrong O, Davies HEF: The excretion of acid in renal disease. Q J Med 1959;28:259-313. 